\title{
EPARMATOSTIGMA DIVES (ORCHIDACEAE), A NEW GENERIC RECORD FOR LAOS
}

\author{
A. SCHUITEMAN ${ }^{1} \&$ P. BONNET ${ }^{2}$
}

\begin{abstract}
SUMMARY
Eparmatostigma dives, previously thought to be endemic to southern Vietnam, is recorded from Laos. Both the vegetative and the generative parts are fully described for the first time.
\end{abstract}

Key words: Eparmatostigma, Orchidaceae, Laos, Vietnam.

The subtribe Aeridinae of the subfamily Epidendroideae (Orchidaceae) contains an unusually high number of monotypic genera. About one third of the circa 102 currently recognised genera in this large and important group are monotypic. This probably indicates that our knowledge of the phylogeny of these orchids is insufficient, causing a certain inflation in the number of genera recognised. In addition, some of the genera are very rare and incompletely known. This certainly applies to the monotypic genus Eparmatostigma, which until now was only recorded from a few localities in the south of Vietnam. The first illustration to appear in the literature was a line drawing of a flower of $E$. dives (Rchb.f.) Garay by Seidenfaden (1992), who noted that the very sparse material in herbaria consisted only of some inflorescences and a few detached leaves. Until now the vegetative parts have never been described. The species was rediscovered about ten years ago by Alexander and Karel Petrželka (pers. comm.) near Loc Ninh in southern Vietnam. They were probably the first to photograph E. dives. According to Averyanov (Averyanov \& Averyanova 2003) this species is very rare and critically endangered in Vietnam.

We were therefore pleasantly surprised when some plants that we collected in the fruiting stage during field work in the Bolikhamxai Province of Laos, close to the border with Vietnam, turned out (using the key in Schuiteman \& De Vogel 2000) to be Eparmatostigma dives, a new record for the flora of Laos (Schuiteman et al. 2006). They flowered for the first time in early May 2007 in the greenhouse of the National University of Laos in Vientiane. Comparison with Seidenfaden's drawing and Petrželka's photographs confirmed the identification. This new locality is about $800 \mathrm{~km}$ to the north-northwest of the Vietnamese sites, and we may expect that this species will also be found in other localities in the poorly known region along the border of Laos and Vietnam.

1) Nationaal Herbarium Nederland, Universiteit Leiden branch, P.O. Box 9514, 2300 RA Leiden, The Netherlands.

2) CIRAD, UMR AMAP (botAnique et bioinforMatique de l'Architecture des Plantes), TA40/PS2, Bd. De la Lironde, 34398 Montpellier cedex 5, France. 

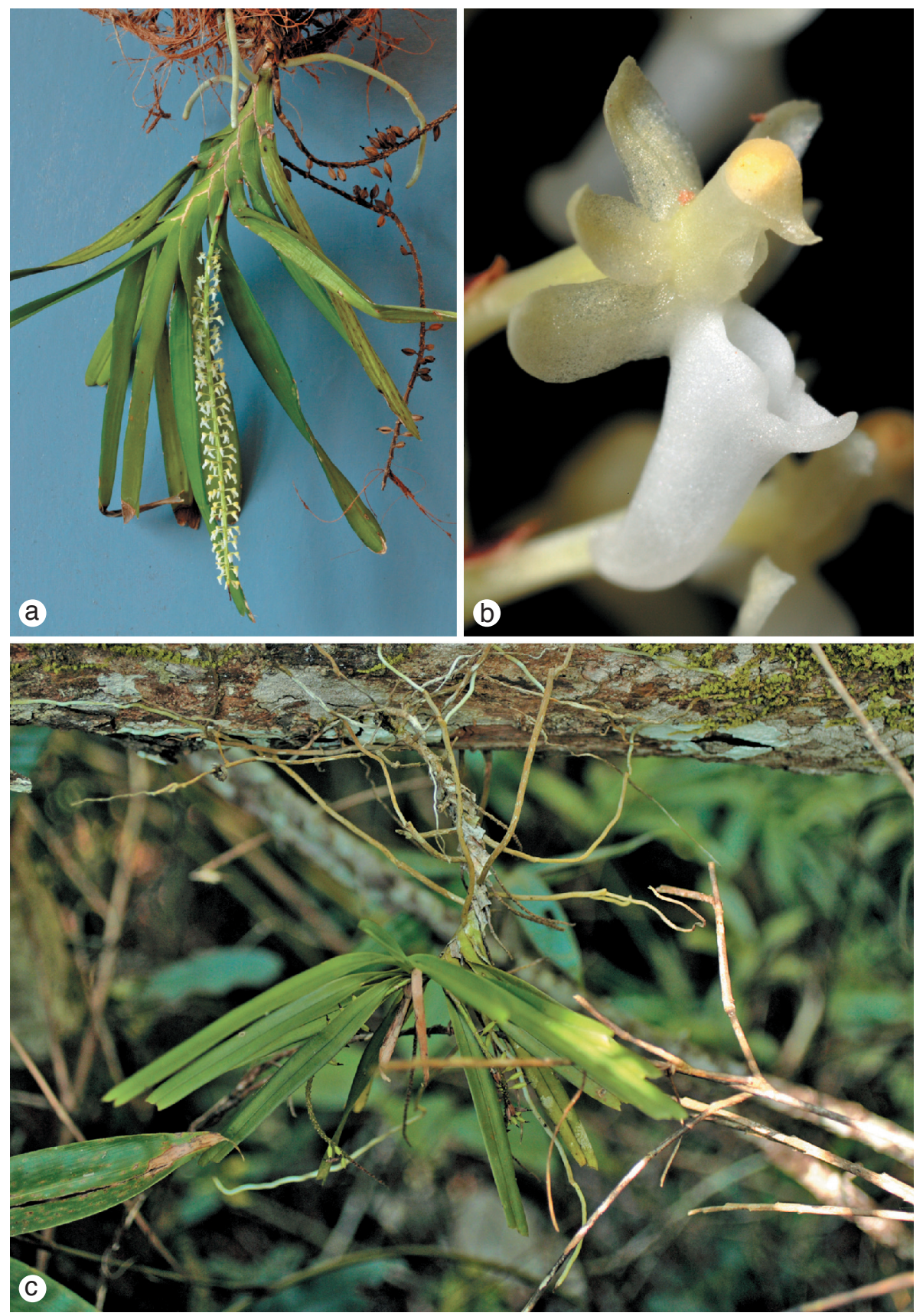

Fig. 1. Eparmatostigma dives (Rchb.f.) Garay. a. Flowering plant; b. flower; c. in situ. Photos: a, b. A. Schuiteman; c. P. Bonnet. 
As Seidenfaden remarked, the flowers are reminiscent of those of Malleola. He considered, however, that the porate pollinia of Eparmatostigma place it in a different group. To this we can now add that the habit is also quite different from Malleola. While in Malleola the leaves are spreading in one plane, those of Eparmatostigma are all in separate planes. They have moreover a smoother, more glossy surface, a more leathery and stiffer texture than those of Malleola and lack the purple tinge often seen in that genus. Superficially the minute flowers also resemble those of Cleisostoma (and allied genera, such as Sarcoglyphis), but here the differences are greater, since Cleisostoma has four, not two pollinia, and the spur is provided with two calli inside. From all genera in the Aeridinae Eparmatostigma differs in the crater-like structure surrounding the stigma, to which the genus name refers: eparmatos, a swelling. Recent molecular work in Orchidaceae has repeatedly shown that vegetative characters are often better indicators of relationships than floral morphology (see for example Cameron 2005), so we may perhaps speculate that Eparmatostigma is more closely related to the Vandal Aerides/Rhynchostylis group of genera than to Malleola or Cleisostoma and that floral similarities with the two last mentioned genera are due to convergence.

Below we present the first complete description of $E$. dives, with some notes on distribution, habitat and ecology.

\section{Eparmatostigma dives (Rchb.f.) Garay - Fig. 1}

Eparmatostigma dives (Rchb.f.) Garay (1972) 179.

Saccolabium dives Rchb.f. (1875) 130.

Saccolabium chrysoplectrum Guillaumin (1930) 333.

Saccolabium chrysoplectrum Guillaumin var. albiflorum Guillaumin (1964) 538.

Roots 2-2.5 mm diam., white with a green apical part, arising from the basal part of the stem; the young roots appear at the base of the oldest leaves. Stem c. $10 \mathrm{~cm}$ long, ascending, densely leafy. Leaf-sheaths closely overlapping, with a c. $1 \mathrm{~mm}$ wide, membranous, scarious margin. Leaves linear, coriaceous, $13-17$ by $1.4-1.7 \mathrm{~cm}$, green with dark green margin, folded at the base, flat distally, each in a separate plane, apex unequally bilobed, often mucronate, the lobes truncate to rounded, mucro short, subulate, not always present. Inflorescence arising from the leaf-axils, racemose, glabrous, to $17 \mathrm{~cm}$ long, more or less pendulous, rather densely many-flowered; peduncle c. $3 \mathrm{~cm}$ long, green, with c. 3 ligulate, basally tubular peduncle scales. Rachis ribbed, slender, c. $14 \mathrm{~cm}$ long, green. Floral bracts triangular, blackish brown, in the basal part of the inflorescence c. $1 \mathrm{~mm}$ long, in the apical part c. $0.5 \mathrm{~mm}$ long, appressed to the pedicel. Pedicel and ovary very slender, 2-3 mm long. Flowers widely opening, $4.5 \mathrm{~mm}$ long, with a weak smell of cucumber. Sepals, petals and column very pale green, lip white. Medium sepal ligulate, 1.5 by $1 \mathrm{~mm}$, subacute. Lateral sepals oblong, slightly oblique, 2 by $1 \mathrm{~mm}$, subacute. Petals oblong, 1.5 by $0.8 \mathrm{~mm}$, obtuse. Lip including spur $3 \mathrm{~mm}$ long, 3-lobed; lateral lobes very short, truncate; midlobe triangular, $0.8 \mathrm{~mm}$ long, acute, slightly incurved, strongly concave, separated from the mouth of the spur by a transverse, slightly emarginate lamella; spur conical-cylindrical, $2 \mathrm{~mm}$ long, 1.2 $\mathrm{mm}$ wide near the mouth, apex slightly recurved, obtuse, inside without ornaments or septum. Column cylindrical, thick, $1.5 \mathrm{~mm}$ long; rostellum short, raised, triangular; stigma with raised margins, crater-like, in outline ovate. Anther ovate in dorsal view, 
$1 \mathrm{~mm}$ long, cucullate. Pollinia 2, spherical, porate, somewhat angular, $0.5 \mathrm{~mm}$ diam., yellowish white; stipe linear, $1 \mathrm{~mm}$ long; viscidium orbicular, $0.2 \mathrm{~mm}$ long. Fruit narrowly ellipsoid, 7 by $2.5 \mathrm{~mm}$ including the almost $1 \mathrm{~mm}$ long pedicel.

Distribution - Southern Vietnam (see Seidenfaden 1992 for localities; also found by A. \& K. Petrželka near Loc Ninh); Laos, Bolikhamxai Province, Lak Xao, near Ban Thaveng (Bonnet \& Schuiteman PB131, NUOL, spirit material), flowered in cultivation at the National University of Laos 10 May 2007.

Habitat - Epiphyte in forest on summit of limestone hill, growing on tree trunk in the shade, altitude c. $650 \mathrm{~m}$. In Vietnam at $200 \mathrm{~m}$ in mixed semi-deciduous forest (K. Petrželka, pers. comm.).

\section{ACKNOWLEDGEMENTS}

We thank the dean and staff of the Faculty of Science of the National University of Laos in Vientiane, especially Prof. Dr. Bouakhaykhone Svengsuksa, for their invaluable support. We are pleased to acknowledge the help and suggestions of Dr. Daniel Barthélémy, project manager of the ORCHIS project (see http://www.orchisasia.org). Our fieldwork, as part of the ORCHIS project, was financed by grant LA/Asia Invest II/03 (114285) under the AsiaInvest programme of the European Union. Prof. Leonid Averyanov kindly provided the first author with reprints of his publications. Alexander and Karel Petrželka sent us their digitised photographs and notes on Vietnamese orchids, for which we are much obliged.

\section{REFERENCES}

Averyanov, L.V. \& Averyanova, A.L. 2003. Updated checklist of the orchids of Vietnam. Vietnam National University Publishing House, Hanoi.

Cameron, K.M. 2005. Leave it to the leaves: A molecular phylogenetic study of Malaxideae (Epidendroideae, Orchidaceae). Amer. J. Bot. 92: 1025-1032.

Garay, L.A. 1972. On the systematics of the monopodial Orchids I. Bot. Mus. Leafl. 23: 149-212.

Guillaumin, A. 1930. Espèces et localités nouvelles d'Orchidées-Vandées d'Indo-Chine. Bull. Soc. Bot. France 77: 326-340.

Guillaumin, A. 1964. Plantes nouvelles, rares ou critiques des serres du Muséum (Notules sur quelques Orchidées d'Indochine XXXVI). Bull. Mus. Natl. Hist. Nat. Paris, sér. 2, 36: 537-539.

Reichenbach, H.G. 1875. New garden plants: Saccolabium dives. Gard. Chron. II (1875) 130.

Schuiteman, A., P. Bonnet \& B. Svengsuksa. 2006 onwards. Preliminary checklist of the Orchidaceae of Laos. Published on the Internet: http://www.orchisasia.org.

Schuiteman, A. \& E.F. de Vogel. 2000. Orchid genera of Thailand, Laos, Cambodia and Vietnam. Nationaal Herbarium Nederland, Leiden.

Seidenfaden, G. 1992. The orchids of Indochina. Opera Bot. 114: 1-502. 